\title{
Influence of Teacher Professional Knowledge and Application on Pupils Academic Performance in Public Primary Schools in Suna East Sub-County Migori County, Kenya
}

Onyango David Diang'a*, Dr. Yambo, J. M. O. PhD, Dr. Kennedy N. Getange, PhD

Department of Educational Administration, Planning and Economics Kisii University Kenya

DOI: $10.36348 /$ sjet.2020.v05i11.011

| Received: 10.04.2019 | Accepted: 18.04.2019| Published: 19.11.2020

*Corresponding author: Onyango David Diang'a

\section{Abstract}

Poor academic performance of most public primary schools in Suna East Sub-County is a serious challenge in Migori County. Out of five zones in the sub-county, there was low learning outcome in the assessment score with a mean standard score of 250 out of 500 marks for the last five years. The objective of this study was to investigate the influence of teacher professional knowledge and application on academic performance. The study used a survey design and both qualitative and quantitative methods of data collection and analysis. This study was based on two theories; the goal setting theory by Edward Locke and Expectant theory by Vroom. The study had a population of 65 head teachers, 65 deputy head teachers and 500 assistant teachers in public primary schools in Suna-East Sub-County Migori County. Krejcie and Morgan table was used to obtain a sample size of 56 Head teachers, 56 deputy heads, and 217 assistant teachers. The study also used both questionnaires and interview schedules to collect data. Validity of the research instruments was determined through open discussion with the supervisors of Kisii University. Reliability of the research instruments was established through test re- test method using questionnaires and interview schedules results. The data collected was analyzed using statistical package of social sciences (SPSS) version 21 to generate descriptive statistics in a correct and informative way. This study would be significant in the field of education in enhancing quality education by the educators. The finding revealed that most of the teachers $163(83.9 \%)$ indicated that they think that professional knowledge is essential in enhancing teaching outcomes, only 33(16.1\%) who did not consent. Professional knowledge is viewed as key in evaluating teachers teaching outcomes. It includes all professional record kept by the teachers to enhance learning and academic outcome. The study recommended maintenance of professional records at all times. It concluded that a teacher should ensure there is effective syllabus coverage by attending all lessons as per the school timetable. The researcher paid keen attention to research ethical issues and got the informed consent of the respondents and guarded against plagiarism and ensured confidentiality.

Key words: Teacher, Professional, Knowledge, Application, Academic, Performance, Kenya.

Copyright (C) 2020 The Author(s): This is an open-access article distributed under the terms of the Creative Commons Attribution 4.0 International License (CC BY-NC 4.0) which permits unrestricted use, distribution, and reproduction in any medium for non-commercial use provided the original author and source are credited.

\section{INTRODUCTION}

Actual work performance should actually be appraised. According to Gardner [1] in the United States of America Educationists were credited for their effort to come up with Performance Appraisal in an effort to appraise employees towards enhancing their work output. The issue of performance appraisal in Cape Town is also evident in the works presented by Callaghan [2] who illustrated the unease surrounding the use of personality based rating that was commonly used then and advocated for a more participative approach including an element of self-appraisal. Selfperformance appraisal approach was most preferred because it focused on what an individual could be able to achieve in the future more than it looked backward. Studies conducted by Deway [3] noted that the evergrowing emphasis on performance appraisal has been attributed to the fact that it seems impossible for supervisors, managers and administrators to effectively manage any organization without the adequate information on how people are performing, and how they meet their responsibilities and set targets. Appraisal information is necessary for critical management functions like maintaining control of current operations and planning for the future, making decisions about compensations and promotions [4].

In Nigeria Fafunwa [5] in his studies on performance appraisal explains that the increasing 
Onyango David Diang'a et al., Saudi J Eng Technol, Nov. 2020; 5(11): 460-468

demand for greater accountability by educational managers has led to a growing emphasis on performance appraisal for academic staff. Staff appraisal has been considered as a high important issue that should be effectively embraced by academic professionals as an essential aspect of their work .He further explains that managers are measuring, evaluating, compensating, designing and changing their systems constantly due to the appraisal knowledge. Studies done by Ayeni [6] proposes that wrong appraisal schemes can lead to inaccurate performance appraisals and therefore low motivation, commitment and loyalty by staff but most importantly poor academic attainment by learners in any organization.

The 1960s appraisal in India presented by Trivediprajapati [7] emphasized goal setting and the establishment of performance related realities which are essential in the general attainment of organizations general set goals, targets and objectives. Performance appraisal therefore should be a yearly rite of passage in organizations that triggers dread and apprehension in the most experienced, battle hardened manager whose main aims and objectives are to enhance the general performance of such organizations. Despised by the evaluators, organizations try to refine the methods linking performance appraisal to other administrative matters including reward, promotions and training, arguing that employees' achievements should not only be measured through appraisals but evaluated and managed. In 1970s in Egypt and Zambia, Appraisal practices became more open to scrutiny and as a result a number of legal cases were brought some of which were for and some against appraisal matters. One quality of this was an increase in research into rating scale and their uses. In Uganda, through the 1980s and 1990s, the Ugandan government took advantage of provisions in the existing laws and regulations to initiate a number of reforms in educational institutions. The concept of performance appraisal and management also came during such a time when a lot of reforms were being done and this according to Prensky [8] provided a more holistic approach to generating motivation, improving performance and managing human resources in school systems. Academic performance has an inclination on socio-economic status of homes and this was evidenced by the work of Nyagiati and Yambo [9] and Nyanda, Yambo and Getange [10] from Tanzania who also argued that children from illiterate and humble homes perform poorer than their counterparts from rich and well to do homes for the required school materials are readily available.

In Kenya, the code of regulation for teachers [11] illustrates that Performance appraisal is mainly meant to improve the general academic standards in learning institutions. The Teachers Service Commission Act [12] also provides an open performance Appraisal system where teachers are expected to strengthen supervision and to continuously monitor the performance of learners and curriculum implementation at institutional level. This is also supported by performance guidelines by government in Republic of Kenya [12] the document which explains that the Teacher Performance Appraisal and development system was mainly introduced into schools in six counties in February 2014 and after 2 years of training it was revised and finalized by the end of 2015 as a tool that is essential in helping raise the learning outcome among the school going learners. This programme aimed at improving teacher's performance and in enhancing the quality of learners' academic performance in schools. The studies done by Wango [13] indicated that performance appraisal tool should consist of seven key areas in enhancing learners academic performance. Such areas include among others:-professional knowledge and application, time management, innovation and creativity in teaching, learner protection, safety, discipline and teacher conduct, promotion of co-curricular activities and professional development in teachers which need to be conducted on a regularly basis. During appraisal teachers are rated on a five point scale: 5 to 1 . Where 5 means fully met and exceeded the target, 4 fully met the target, 3 met most of the target, 2 met some of the target and 1 did not meet the target with their various percentages. This kind of rating takes into consideration the most crucial parts teachers are supposed to play to meet the general set targets for academic excellence.

According to studies done by Kobia and Mohamed [14] in Kenya teacher performance appraisal and development clearly explains how a competent teacher is expected to behave with an aim of improving the teaching standards in both public and private schools. The study further explains that appraisals are generally focused on the individual and what they do; in Asian cultures for example (strong collectivism) the 'sense of hierarchy and acceptance of authority, the focus on 'western' performance appraisal practices on individual performance, accountability and open confrontation are unlikely to be seen as appropriate as this may differ from one culture to the other. Researchers and Educators have emphasized that appraisal reactions play a crucial role in the development of favorable job and organizational attitudes and enhance motivation which finally increase he general performance of an institution or organization.

In Migori County Performance Appraisal has been embraced with a lot of enthusiasm especially in Suna East Sub-County where this study was conducted. This is due to the fact that educational Stakeholders have realized it is the only way to ensuring better teaching outcomes in Migori educational institutions both public and private. Studies done by Migori District education stakeholders [15] noted that it has helped the educational workforce to be more productive. This is in 
terms of time management, professional development, creativity and innovation and teacher professional development among many other educational teaching standards and requirements. According to studies done by Richard [16], the reforms about Performance Appraisal are aimed at improving efficiency and effectiveness, while reducing costs. In this case effectiveness refers to goal accomplishment while efficiency evaluates the ratio of outputs consumed to outputs achieved. The board in their studies suggests that the greater the output for a given input, the greater the efficiency. Performance appraisal therefore strives at ensuring teachers use the right teaching methods during teaching, as well as managing their work in a more professional manner. The requirements of proper performance appraisal seem to be a major challenge in Suna East Sub County, a gap which this study aims at filling.

According to Migori Education Stakeholders [17] effective and efficient performance and academic outcome requires teachers to prepare for the lesson in advance, with all the necessary professional documents. Although teachers From Suna East Sub-County use relevant teaching and learning materials for teaching, they still carry with them text books to class meaning they are not adequately prepared for the lessons. They use text books to make notes for the learners and at the same time teach. This tendency consumes a lot of their time making their lessons to be less efficient and effective. Performance appraisal therefore is aimed at correcting these problems especially in Suna East SubCounty public primary Schools. There are also occasions noted when teachers are late for lessons or miss lessons for no apparent reason even when physically present in learning institutions. Others also waste a lot of time teaching what is not relevant to the lesson planned. It is only through performance appraisal where these problems can be investigated and addressed especially in Suna East Sub-County public primary schools where this study has been conducted revealing the following results in table 1.1

Table-1: KCPE Academic performance for the three Zones in Suna East Sub-County Public primary Schools for the last 5 Years (Suna East Sub-County K.C.P.E Examination Analysis Report of 2017)

\begin{tabular}{|l|l|l|l|l|cc|}
\hline \multicolumn{1}{|c|}{ ZONES } & \multicolumn{5}{|c|}{ KCPE YEAR/MEAN SCORES } \\
\hline ZONE & $\mathbf{2 0 1 3}$ & $\mathbf{2 0 1 4}$ & $\mathbf{2 0 1 5}$ & $\mathbf{2 0 1 6}$ & $\mathbf{2 0 1 7}$ & $\mathbf{2 0 1 8}$ \\
\hline Anjego & 230 & 220 & 215 & 218 & 239 & 228 \\
\hline God-Jope & 225 & 221 & 218 & 229 & 244 & 235 \\
\hline Migori & 248 & 247 & 248 & 253 & 252 & 251 \\
\hline Sub-county MSS & $\mathbf{2 3 4}$ & $\mathbf{2 2 9}$ & $\mathbf{2 2 7}$ & $\mathbf{2 3 3}$ & $\mathbf{2 4 5}$ & $\mathbf{2 3 8}$ \\
\hline
\end{tabular}

Source: Ministry of Education (2018).

The highest sub counties mean score for the last six years is 245 marks. This mean score is below the expected average of 250 marks. The general means for all the three zones for the last six years is also very low .This therefore justified the need to investigate the influence of Teacher Performance Appraisal and Development on teaching outcome in primary Schools in Suna East Sub-County, Migori County Kenya.

\section{Statement of the Problem}

The problem of low academic performance in Suna-East sub-county public primary schools in Migori County is seriously on a worrying trend as in table 1 . Many learners drop out of school and are unable to join secondary schools and other middle level technical learning institutions to meet the government effort of a hundred percent transition rate and acquisition of relevant skills for the general development of the Kenyan economy. Inspite of those who drop out of school, the learners who struggle to complete their education circle still perform poorly despite the numerous resources the government and other development partners provide. According to the Republic of Kenya [18] Migori county evaluation annual report many learners are still not able to perform simple tasks including operating basic arithmetic and reading. After school, they continue to languish in abject poverty and this puts a lot of strain in the Kenyan economy in terms of labor force, economic resources and skilled manpower. The government has formulated a number of policies aimed at ensuring a better academic performance in all learning institutions but this has not helped much. It has also formed several task forces to help find out why there is low academic performance among the learners through assessments. According to TSC [19], academic performance in schools is still very low and needs a very urgent attention. In Suna East sub-county, this is evident in table 1.1 where this research was conducted with an aim of investigating whether performance appraisal and development has any influence on academic performance in public primary schools. This study therefore noted with a lot of concern that despite the performance appraisal tool academic performance in Suna East sub-County public primary schools is still a major challenge that needs very urgent attention.

\section{Teacher Professional knowledge and application on pupils academic performance}

A study done in Nigeria by Ayeni [6] indicated that educational enterprise involves development of human intellect, technical skills, character and effective citizenship. consequently the issue of quality assurance in education which has become a matter of great concern for the government, educational institutions and other stakeholders in order to meet expectations of 
the society. Teachers are expected to have sound knowledge of their subject areas to be able to select appropriate and adequate facts for the planning of lesson notes, effective delivery of lessons, proper monitoring and evaluation of students performance, providing regular feedback on students' performance, improvisation of instructional materials, adequate keeping of records and appropriate discipline of students.

The work of Fullan [20] on Teacher Professional Development is the sum total of formal and informal learning pursued and experienced by the teacher in a compelling learning environment under conditions of complexity and dynamic change. A common underpinning assertion of the above definition is continuing learning process, by which serving teachers acquire the knowledge, skills and values to sustain the desired spark of intellectual vitality, which will improve the quality of teaching and students learning outcome. Teachers are known to be responsible for the translation and implementation of educational policies. These depend on professional practice. According to Ayeni [6] Teachers who are deficient in professional practice are not likely to help the students meet the challenges of learning.

Teacher's professional development is particularly important because of the need for teachers to do better and raise academic performance standards of students. In order to meet the challenging demands of their jobs occasioned by technological innovations, teachers must be capable and willing to continually upgrade their content knowledge, skills and practices. Although, there are various approaches to teachers professional development such as the cluster-type workshops, mentoring and full-time in service training; whichever approach one adopts for teachers training, the important thing is for the teacher to be professionally equipped as is asserted by Hayes [21].Teachers Service Commission has come up with timely policies to help guide Teachers professional Development to help improve performance Appraisal outcome.

Teacher's professional development is informed by the fact that if teachers are to stay motivated on the job, they must have opportunities for continuing professional development, advancement and improvement in their chosen careers [22] indicates that effective teachers' professional development is critical to quality learning outcome in education and to a larger extent determines students' academic outcome. However, gaps in teachers' professional development will no doubt cause set-backs in teaching-learning process.

\section{RESEARCH METHODOLOGY Research Design}

This research used survey design which according to Chandran [23] it is extensive, flexible and dependable and is useful in describing the characteristics of a larger population. Survey design ensures a more accurate sample to gather targeted results in which to draw conclusions and make important decision.

\section{Area of Study}

The study was carried out in Suna East SubCounty public primary schools in Migori County, Kenya. This is because there is no any empirical research on Performance Appraisal and Development that has been done in this area. According to Maurice, Cleophas and Evans [22] and the statistics on academic performance taken from the Ministry of Education [25] in Migori Suna East Offices, Migori County, Suna East Sub-County has four county assembly wards namely God Jope, Suna Central, Kakrao and Kwa. The SubCounty is located in Migori County in South Nyanza.Its bordering uriri constituency to the south, kuria east to the south Suna west and Nyatike to the west. It is a cosmopolitan Sub-County with majority of the population inhabited by the luos,then the luhya,Kisii and the kuria tribes. It also has a few Somalian and Indian communities. The major economic activity in this Sub-County is tobacco and sugarcane growing and other small scale horticultural farming. It has a population of 97121 people [26] with an area of 207.30 square kilometres with latitude of -1.0634 and longitude of 34.4731 .

The Sub-County has always registered the highest sub-county academic mean of 245 in the Kenya Certificate of Primary Education (KCPE) which is below average according to Kenya national examination council rating. In the year 2013 the KCPE mean was 234; in 2014 the mean was 229; in 2015 the mean was 227 in 2016 the mean was 233 in 2017 the mean was 245 and in the year 2018 the mean was 238 . The means are also not stable. There was therefore the need to investigate the cause of this dismal learning outcome. It was established in the year 2013 when Migori constituency was divided into Suna west and Suna East Sub-Counties. The drainage pattern is punctuated with two permanent rivers that flow into Lake Victoria. The Sub-County has two rainy seasons that falls between December to May and between February and April every year [18].

\section{Target Population}

According to Kothari [27] research population is a large collection of individuals or objects known to have similar characteristics and is of interest to a researcher. Studies further done by Kothari indicate that research population represents the total group of people or entities from which information is required. The target population for this study was 65 Headteachers, 65 
deputy head teachers and a total of 500 assistant teachers. Data will also be collected in public primary schools only. This is because most private schools do not follow the performance appraisal demands by the Ministry of Education and the Teachers Service Commission since they have their own internal appraisal systems. This population encompasses three zones; Migori with a total of 18 public primary schools, God-Jope with a total of 24 public primary schools and Anjego zone with a total of 25 public primary schools.

\section{Sampling procedure and sample size}

A sample is a subset of the population [28]. A Sample size is the number of items to be selected from the universe to constitute a sample. It is a part of large body specially selected to represent the whole. Out of a population of 65 headteachers, 65 deputy headteachers and 500 assistant teachers, the researcher will use Krejcie and Morgan [26] formular to obtain a sample size of 56 Headteachers, 56 Deputy Heads, and 217
Assistant teachers. It used stratified random sampling that gave each item in the population an equal chance of being selected to identify senior teachers and Assistant teachers. Each school of focus was considered as a stratum. A ratio of 0.4 was used to select a sample from each stratum. This was supported by Kothari [27] in his studies done in New Delhi that talks about the method used to identify a sample within a population. For the headteachers and their deputies, purposive sampling technique was used. Purposive sampling in this case will imply explicitly selecting headteachers and deputy heads who are likely to generate appropriate and useful data [29]. This was considered because they are considered to have the required information, like government circulars and policy documents that guide teachers service delivery as far as teacher's appraisal is concerned. They are also the ones appraise and observe the rest of the teachers. The researcher used Krejcie and Morgan [26] table to generate the required samples in table 2 .

Table-2: Population of each category of respondents

\begin{tabular}{|l|l|l|l|}
\hline Respondents & Population & Krejcie \&Morgan Table & Sample population \\
\hline ASS TEACHERS & 500 & 500 & 217 \\
\hline D/ HTRS & 65 & 65 & 56 \\
\hline HT & 65 & 65 & 56 \\
\hline TOTAL & $\mathbf{6 3 0}$ & & $\mathbf{3 2 9}$ \\
\hline
\end{tabular}

From table 2, when 65 Head teachers and deputy Head teachers were selected the population translated to a sample population of 56 head teachers and 56 deputy Head teachers which was done using simple random sampling. On the other hand when a population of 500 teachers was selected, a sample population of 217 was realized. The assistant teachers during this study was chosen using proportionate random sampling while the schools where this study was done was chosen using proportionate stratified random sampling, where population was divided into groups based on similar characteristics as is supported by Kothari [27].

\section{Instruments of Data Collection}

Research instruments are tools that a researcher will use in collecting data from the sampled research population. Quantitative survey data collection method was employed to collect primary data. Questionnaires and interview schedules was developed and used in this study [30].

\section{Questionnaires}

According to Richard [16] questionnaires are chosen due to its ability to collect a large number of information in a reasonably quick space of time. The advantage of this approach was that the researcher collected data from a controlled number of variables or unlimited number of variables. The questionnaires had both open and closed set of questions. Closed ended set of questions in the questionnaire was used to restrict respondents while open ended set of questions in the questionnaire will be used to get the opinion of the respondents.

Questionnaires for Head teachers, deputy Head teachers and teachers were issued by the researcher to seek information on influence of Teacher Performance appraisal and development on academic performance in primary schools in Suna East Sub-County, Migori County-Kenya. Since they are presented on paper form, there was no opportunity for interviewer's biasness. This is supported by Orodho [31] in his studies done in Nairobi Kenya. In his work he further states that Questionnaires also enable the person administering them to explain the purpose of the study and the meaning of items that may not be clear. The researcher cooperated with the respondents to administer the questionnaires to the Head teachers, deputy head teachers and assistant teachers. The Questionnaires (Appendices A, B, C) was used to collect data from the sampled population. Likert scale was used to measure the attitude of the respondents in objective three. There were five responses that were checked and numerical score were assigned to each of the questions with responses ranging from strongly agree, agree, neutral, disagree and finally strongly disagree.

\section{Interview Schedules}

Interview schedules according to Fazal [12] are documents that have a list of questions that a researcher administers to the respondents on face to face or through telephone, e-mail, and radio or through television. Face to face interviews was used by the 
researcher to enlist In-depth information from some respondents of the same population especially what was not clear from the other respondents of the questionnaires. Focus interviews for some respondents within the group of the research was conducted by the researcher after the questionnaires have been filled out. This was done deliberately so as so seek for more information and clarification from the interviews on the issues not adequately addressed in the questionnaires [28] Head teachers, Deputy Head teachers and assistant teachers within the sampled population were interviewed.

\section{Validity of research instruments}

According to Daniel [17] Validity is the appropriateness, meaningfulness and usefulness of a specific inference the researcher make on the data collected. It is the degree of success with which the results obtained from analysis of the data collected actually represent the phenomenon under study. He further emphasized that validity is the degree of success with which the instrument measures what it is supposed to measure; the accurateness, correctness, true and meaningfulness a point supported by Jehn et al. [32]. In order to check the content and construct validity of the instruments, questionnaires were first scrutinized by the University Supervisors where they made necessary corrections incorporated in the study. Content validity was established through discussions with Research Experts from Kisii University in the department of Education.

\section{Reliability of the instrument}

According to Kothari [27] reliability is the measure of the degree to which a research instrument yields a consistent results or data after repeated trials. He further suggests that validity is the extent to which one's findings can be replicated. During this study reliability was established through test re-test method. The research questionnaire was administered to 15 respondents within the research area who are not included in the study. One month later, the questionnaires were administered to the same respondents. The major purpose of the pilot study was to check on the suitability and the clarity of the questions, relevance of the information being sought, the language to be used and the content validity of the instruments from the responses given. To ensure reliability, the researcher delivered the questionnaires to the sampled primary schools directly, administered them to the head teachers, deputy head teachers and teachers and clarified each item to ensure the respondents understood the choices under the rating of items. The researcher finally accepted a reliability of 0.70 as reliable using Pearson correlation coefficient formula.

\section{Data Collection Procedures}

Before data was be collected, permission was sought from Kisii University Supervisors and the Kisii University research department which with their consent an application for research permit was done to NACOSTI before the researcher proceed to the field to collect relevant data with permission from county director of education and county commissioner as was instructed by the director from NACOSTI. Pilot questionnaires were prepared and administered to sampled respondents in 16 schools to ensure the clarity and objectivity of the items. This greatly assisted the researcher to make necessary adjustments in the original questionnaires due to some unavoidable demands from the piloted respondents. Questionnaires were pre-tested and suggestions for improvement encountered during the piloting process were in cooperated in the final questionnaires. Final questionnaires were distributed to the respondents by the researcher himself without the research assistants. The researcher collected data from 56 headteachers, 56 deputy head teachers and 217 assistant teachers in the 65 public primary schools in Suna East Sub-county; though not all the questionnaires were returned as is explained in chapter four of the study. To improve the response rate, there was a cover letter explaining the reasons for the research from both the county director of education and county commissioner. This made respondents more comfortable to freely respond to the questionnaires.

\section{DATA ANALYSIS}

According to Kothari [27] data collection from the respondents was processed using the data processing Operations which include editing to ensure accuracy and consistency, coding in order to put data into groups on the basis of common characteristics and finally tabulation in order to summarize and arrange the data in a concise and logical order. Descriptive statistics was then used to compute the mean, frequencies and percentages along with the search for patterns of relationships that exists from the collected data. A study done in London by Creswell [33] further illustrate that Descriptive statistics was used because it deals with methods of organizing, summarizing and presenting data in a convenient and informative way. This was achieved by use of tables and charts which allow presentation of data in ways that make it easier for readers to see information that may not be apparent to a casual observer. Whereas graphical techniques enhance mental perception of the information, numerical techniques are used to give summation, frequency percentage and average or mean to consolidate data. Frequency tables and pie chart graphs will be used to analyze the relationship between the teacher performance appraisal and development on teaching outcomes. The descriptive statistics will then be presented using tables, graphs and charts. Statistical software package for social sciences (SPSS) version 21 was used to generate the required descriptive statistics. 
Frequency tables, charts and other simple statistical analytic techniques were also used to analyze the data that was generated. According to studies done by Mugenda [28], Pearson correlation formula was used to determine the relationship between independent and dependent variables

\section{Ethical Considerations}

According to Homets [30], Ethics is the norm of conduct that distinguishes between an acceptable and unacceptable behavior in a given society. This research was guided by the following ethics; openness, honesty, confidentiality and social responsibility. The study strived to ensure there was a lot of honesty in data presentation and analysis as is emphasized by Kothari [27]. It was open to any possible criticism as the researcher strived to upheld confidentiality of any form of information obtained from different respondents. Social responsibility during this study was aimed at promoting the social good and at the same time prevented any social harm through research, publication education and advocacy. Relevant laws, policies and rules were observed during this study. This was due to the fact that this kind of research was conducted in schools which are governed by different rules and policies created by the government and other relevant educational stakeholders. The participants participated on open and voluntary basis. Privacy of the respondents was highly upheld and none of the respondents was coerced into participation. The respondents were treated with respect and courtesy throughout the research period. Rules in research and publication including the rules on plagiarism were observed. The document was also subjected to anti plagiarism tests; where it was realized to have obeyed the set rules and regulations of the Kisii University.

\section{Findings}

Investigation of the influence of Teacher Professional Knowledge and Application on academic performance in Suna East Sub-County public Primary Schools Migori County, Kenya

Table-3: In your own opinion, do you think professional knowledge is essential in enhancing academic performance?

\begin{tabular}{|l|l|l|l|l|l|}
\hline \multicolumn{2}{|c|}{} & Frequency & Percent & Valid Percent & Cumulative Percent \\
\hline \multirow{2}{*}{ Valid } & Yes & 163 & 83.9 & 83.9 & 83.9 \\
\cline { 2 - 6 } & No & 33 & 16.1 & 16.1 & 100.0 \\
\hline & Total & 196 & 100 & 100.0 & \\
\hline
\end{tabular}

Most $163(83.9 \%)$ of the teachers indicated that they think professional knowledge is essential in enhancing teaching outcomes, only $33(16.1 \%)$ who did not agrees. Professional knowledge is viewed as key in evaluating teachers teaching outcomes. It includes all professional record kept by the teachers to enhance learning and academic outcome. According to TSC TPAD tool [34], professional knowledge promotes performance index which enhances knowledge in subject content areas. It also helps in improving scores in tests and examinations. It further enhances ability of the teacher to recall learnt content and the application of knowledge learnt in solving practical problems for effective syllabus coverage and hence better academic performance.

Table-3: How frequent do you conduct departmental/subject panel meetings towards enhancing academic performance?

\begin{tabular}{|c|c|c|c|c|}
\hline & Frequency & Percent & Valid Percent & Cumulative Percent \\
\hline None & 107 & 55.7 & 55.7 & 55.7 \\
\hline often & 4 & 2.0 & 2.1 & 57.8 \\
\hline once a month & 4 & 2.0 & 2.1 & 59.9 \\
\hline once a term & 8 & 4.1 & 4.2 & 64.1 \\
\hline rarely & 22 & 11.2 & 11.5 & 75.5 \\
\hline termly & 39 & 19.9 & 20.3 & 95.8 \\
\hline thrice a month & 4 & 2.0 & 2.1 & 97.9 \\
\hline when necessary & 4 & 2.0 & 2.1 & 100.0 \\
\hline Total & 192 & 98.0 & 100.0 & \\
\hline Total & 196 & 100.0 & & \\
\hline
\end{tabular}

Majority $107(55.7 \%)$ of teachers suggested that they do not hold /conduct departmental/subject panel meetings towards enhancing teaching outcome in schools. 22(11.5\%) indicated rarely , 39(20.3\%) said termly, and others indicated once in a term, when necessary and once in a month. Meeting to evaluate the teaching methodologies is encouraged to enhance teaching outcomes among teachers in school.

In an interview with teachers they revealed the reasons why they think teachers prefer teaching without approved professional records this include 
Onyango David Diang'a et al., Saudi J Eng Technol, Nov. 2020; 5(11): 460-468

demoralization in terms of lack of promotion and too much writing, lack of knowledge and experience, inaccurate content delivery, it is time consuming, it is time wasting, lack of accountability, have knowledge and experience, poor coordination among teachers, lack of books, readymade schemes of work, laziness, lack of strictness by supervisors, poor planning, poor coordination among administrators, some teachers prefer teaching using old schemes, lack of commitment, and they have knowledge and experience having taught the same subject for long time. To avoid halo error, the administrators should remember that teachers are often strong in some areas and weak in others. This is according to studies done by Buytendijk [15]. Conflict of interest constantly happens in any organization.one of the reasons for this is because of the practice of performance appraisal activities. Further studies done by Lin and Lee [35] suggests that conflicts occur because of the disagreements of the teachers regarding the implementation of the performance appraisal process including desire for honest feedback versus desire for self-concept affirming feedback and recognition [36]. Departmental meetings therefore assist in correcting appraisal related challenges towards enhancement of quality academic performance in institutions of learning.

\section{Which are the challenges that lead to untimely syllabus coverage in your school?}

According to the research findings, untimely syllabus coverage is due to; a lot of work in school, lack of teaching and learning materials, some teachers use text books to teach, lack of early preparation, absenteeism of learners and teachers, co-curriculum activities and sporting activities which come in within the term and is not planned, poor time management by both teachers and learners, lateness by learners and teachers, lack of revision materials, teachers personal commitments, poor health problems of some teachers and learners, transfers in the course of the year, failure to follow timetable, high population that cannot be managed by the available teachers, lack of early preparation and lack of morale among teachers, some teachers go to school but fail to attend to their lessons appropriately. This argument is also supported by Letsoalo [37].Teachers therefore need to take their work with a lot of seriousness following the laid down rules and regulations by the teachers service commission and the ministry of education for a better academic performance in schools.

\section{CONCLUSION}

Most of the research evidence shows that a teacher should ensure there is effective syllabus coverage by attending all lessons as per the school timetable. All the lessons missed must be recovered and the recovery records maintained. He must ensure timely preparation and submission of all professional records as per the school and ministry requirements.as a professional he must attend to all the school activities and staff meetings where issues concerning ways of enhancing learning and teaching outcomes are discussed.

\section{RECOMMENDATIONS}

As far as Teacher professional knowledge and application is concerned, performance appraisal should ensure teachers prepare schemes of work and lesson plans derived from the syllabus and the curriculum. They should plan ahead to meet deadlines and submit the professional documents for approval by the administrators. It should not only be conducted to take promotional decisions for teachers as is suggested by the TSC rather it should focus on improving teachers performance and to develop teachers professional development for better learning outcomes in schools. Learners classwork should be regularly checked to ensure all learners have done the assignments and have written notes.it should also ensure learner's progress records are maintained. This requires the teacher to set marks and revise continuous assessment tests and analyze results. It's important to find out the value added progress and plan for remedial lessons. As the teacher sets his targets at the beginning of the term, he should involve the learners by ensuring he prepares and use teaching aids and varied teaching approaches which are learner centered.

\section{REFERENCES}

1. Gardner, H. (2010). Five Minds for the Future.in Bellanca, J., \& Brandt, R (Eds.), $21^{\text {st }}$ skills: Rethinking how students learn. Bloomington, IN: Solution Tree.

2. Callaghan, A. (2005). Performance Management: SDFs in the Fasset Sector. Cape Town: Fasset

3. Deway, J. (2009). Experience and Education. New York: Collier Books publishers

4. Friesen, S., \& Jardine, D. (2010). 21 $1^{\text {st }}$ Century Learning and Learners. In Government of Alberta. Retrieved April 12,2011 from education.alberta.ca/

5. Fafunwa, A.B. (2005). History of Education in Nigeria. (9th edition) .Ibadan: NPS Educational Publishers limited

6. Ayeni, A.J. (2010). Teachers Instructional Task Performance and Principals Supervisory Roles as correlates to quality assurance in secondary schoolsin ondo state. Unpublished doctoral dissertation, obafemi Awolowo University, IleLfe, Nigeria

7. Trivediprajapati, P. (2010). Performance Contract.Washington.DC: The World Bank.

8. Prensky, M. (2010). Teaching Digital Natives:Partnering for Real Learning.Thousand Oaks: CA: Corwin press

9. Nyagiati, N. A., \& Yambo, J. M.O. (2018). Examination of Teachers' Attitude towards Open Performance Appraisal on Pupils' Academic Achievement in Public Primary Schools in Serengeti District, Tanzania. Journal of Advances in Education and Philosophy, 2(5) 358-366 
Onyango David Diang'a et al., Saudi J Eng Technol, Nov. 2020; 5(11): 460-468

10. Nyanda, L.F., Yambo, J.M.O., \& Getange. K.N. (2018). Financial Challenges Facing NonGovernmental Organisations' in Promotion of Education in Musoma District, Tanzania Journal Sub- of Advances in Education and Philosophy, 2(5)348-357

11. Kenya Education Management Institute (KEMI). (2015). Effective Resource Management. Nairobi: KEMI.

12. Fazal, S. (2012). The role of Study Skills in Academic Achievement of students. A closer focus on Gender. Pakistan. Pakistan Printers

13. Wango, A. (2009). School Administration and Management; Quality Assurance and Standards in Schools. Nairobi. Jomo Kenyatta Foundation. Nairobi Kenya.

14. Kobia, M., \& Mohamed, N. (2006). The Kenyan Experience With performance Contracting. African Association of Public Administrators, 28th Annual Round table Conference. Nairobi Kenya

15. Buytendijk, F. (2009). Performance leadership: The next practices to motivate your People industry. McGraw Hill

16. Richard, C. G. (2002). The Performance Appraisal Question and Answer Book. Survival Guide for Managers: 28-29

17. Daniel, C. (2009). "The effects of higher Education Policy on Location of Individuals Evidence from Florida's Bright future scholarship programs." Regional Science and Urban Economics, 553-562.

18. Ministry of Education. (2018). Migori County Education Annual report, Migori, Kenya

19. TSC. (2016). Teachers performance Appraisal \& Development (TPAD) manual.

20. Fullan, M. (2002). Change Forces: Probing the Depth of Educational Reform. Falmer Press

21. Hayes, J.H. (2010). Curriculum 21: Essential Education for changing World. Alexandria, $V A: A S C D$

22. Fullan, M. (2002). Principals as Leaders in a Culture of Change. Educational Leadership. 59(8), 16-21

23. Chandran, E. (2005). Research Methods: A Quantitative Approach. DayStar University. Nairobi. Kenya

24. Maurice, R., Cleophas, O., \& Evans, M. (2013). Living Together in our County. Longhorn Publishers. Nairobi Kenya
25. Republic of Kenya. (2012). Performance guidelines, Nairobi: Performance Contracting Division, Ministry of Devolution and planning Jomo Kenyatta Foundation, Nairobi, Kenya

26. Krejcie, R.V., \& Morgan, D.W. (2009). Determining Sample Size for Research Activities. Journal of Educational and Psychological Measurement, 30,607-610

27. Kothari, C.R. (2007). Research MethodologyMethods and Techniques; $2^{\text {nd }}$ revised Edition .New Ages International (p) Limited Publishers. New Delhi.

28. Mugenda, O.M., \& Mugenda, A.G. (2010) Research Methods and Qualitative Approach. Nairobi. Acts Press Publishers

29. Kazdin, A. E. (2003). Research Design in Clinical Psychology. $4^{\text {th }}$ Edition.Boston:Allyn and Bacon

30. Homets, H. (2007). Foundation of Behaviour Research ( $2^{\text {nd }}$ Edition) New York. Comey Publishers.USA

31. Orodho, J.A. (2002). Research Methods in Social Sciences. Nairobi UNES Enterprises, Nairobi, Kenya.

32. Jehn, K.A., Gregory, B., North, C., \& Margret, N. (2004S). "Why Difference Make a Difference: Afield Study of Diversity, Conflict and Performanc in Work Groups. Administrative Science Quarterly, 44(4):741-763.

33. Creswell, J.W. (2013). Research design: Qualitative, quantitative and mixed method approaches (2nd Ed.) London: Sage publications

34. Teachers service Commission (TSC). (2016). Performance Appraisal and Development. Nairobi: TSC, Jomo Kenyatta Foundation, Nairobi.

35. Lin, J. S., \& Lee, P. Y. (2011). Performance management in public organizations: a complexity perspective. International public management review, 12(2).

36. Dooren, W. (2006). Performance measurement in the Flemish public sector; a supply and demand approach.(unpublished $\mathrm{PhD}$ thesis) Catholic University, Leuven

37. Letsoalo, B. (2007). An evaluation of performance management in public service. University of Johannesburg. 